\title{
THE INFLUENCE OF WELDING CURRENTS ON THE MECHANICAL AND PHYSICAL PROPERTIES OF CHROMIUM-MOLYBDENUM STEEL
}

\author{
M. S. Kaiser ${ }^{1, *}$ and K. M. Shorowordi ${ }^{2}$ \\ ${ }^{1}$ Directorate of Advisory, Extension and Research Services, ${ }^{2}$ Department of Materials and Metallurgical \\ Engineering, Bangladesh University of Engineering and Technology, Dhaka- 1000, Bangladesh. \\ ${ }^{*}$ Corresponding e-mail: mskaiser@iat.buet.ac.bd
}

\begin{abstract}
An attempt has been made to determine the strength and impact properties of Cr-Mo steel base metal and joints welded by varying the current during manual metal arc welding. A set of sample is heat treated at $650^{\circ} \mathrm{C}$ for 2 hours and cooled in furnace to room temperature. Microstudy of the welded Cr-Mo steels is performed to make relationship with properties. Microhardness and hardness are measured at different locations viz., base metal, heat affected zone (HAZ) and weld deposit. Toughness over a temperature range from -32 to $100{ }^{\circ} \mathrm{C}$ of three zones at three current settings is measured. It is found that toughness of all three zones at $-32{ }^{\circ} \mathrm{C}$ is almost same for any current settings. The toughness at HAZ area are higher than that of deposited weld area due to the coarsening of ferrite grain of HAZ occurs with higher heat input. The hardness and tensile properties of three zones with different welding current is also discussed.
\end{abstract}

Keywords: Chromium-Molybdenum steel, heat affected zone, microstructure, micro hardness, post-weld heat treatment.

\section{INTRODUCTION}

Chromium-Molybdenum steels (Cr-Mo steels) are used as thick plates for pressure vessels in oil refinery, coal liquefaction and coal gasification where service temperature and pressure maintain up to $600^{\circ} \mathrm{C}$ and 30 $\mathrm{MPa}$ respectively. The $\mathrm{Cr}-\mathrm{Mo}$ steel includes 0.09 to $0.17 \mathrm{wt} \%$ of carbon, 0.03 to $0.50 \mathrm{wt} \%$ of silicon, 0.45 to $0.70 \mathrm{wt} \%$ of manganese, 1.80 to $3.40 \mathrm{wt} \%$ of chromium, 0.50 to $1.20 \mathrm{wt} \%$ of molybdenum, 0.035 to $0.1 \mathrm{wt} \%$ of aluminum and 0.0010 to $0.0040 \mathrm{wt} \%$ of boron and the balance iron ${ }^{1}$. The $\mathrm{Cr}-\mathrm{Mo}$ steel of such compositions is excellent for high-temperature strength, toughness and hydrogen attack resistance applications and with the increase of concentration these properties are increased ${ }^{1,2}$. Cr-Mo steels are readily weldable with the conventional arc welding and electroslag processes. Different types of components of the pipelines in the refineries are manufactured from chrome-molybdenum alloy steel. Reduction of internal stresses in chrome-molybdenum steel welded joints can be provided only by thermal treatment ${ }^{3,4}$. Alloy content of the base and weld metal, and associated thermal cycle during welding demand that correct welding procedures including preheat, postweld heat treatment, low-hydrogen consumables and proper filler metal chemistry are required to prevent cracking of heat affected zone (HAZ) and weld-metal $^{5}$. Effects of welding parameters (i.e. heatinput, filler metal composition, number of passes) on the mechanical properties and influence on the microstructure were studied to control the cold cracking and provide adequate toughness of weld zone for resistance to fatigue cracking ${ }^{6,7}$. Improve mechanical properties associated with alteration of weld zone microstructure is a great concern and various attempts are being made to optimise weld productivity with adequate toughness by controlling welding heat ${ }^{8}$.

In the present work, an attempt has been made to determine mechanical properties of Cr-Mo base steel, HAZ and deposited weld metal by varying the current during manual metal arc welding. Microstructure of these areas is also studied.

\section{EXPERIMENTAL}

The material used in the present investigation was obtained in the form of a Cr-Mo steel pipe having 132 $\mathrm{mm}$ outer diameter and $20 \mathrm{~mm}$ thick. A single-vee butt joint with an angle of $60^{\circ}$ and a root face of 1.5 $\mathrm{mm}$ was prepared along the circumference of the pipe. The pipe was preheated at temperature about $300^{\circ} \mathrm{C}$ before the welding operation. Shielded metal arc welding process was used for welding joint. Metal deposited at welding joint from a flux covered electrode of $4 \mathrm{~mm}$ dia consisting of a core wire of matching alloy contents of base metal associated by an alternating current (AC) power source. Variation in welding current $100 \mathrm{~A}, 150 \mathrm{~A}$, and $250 \mathrm{~A}$ with a constant voltage of $50 \mathrm{~V}$ was considered as the welding process variables. The chemical composition of the Cr-Mo alloy steel pipe (base metal) and the weld metal (deposited metal) used in the present investigation were determined using wet chemical method and are given in Table 1. Postweld heat treatment (PWHT) was conducted in the holding temperature at $650^{\circ} \mathrm{C}$ for two hours followed by furnace cooling to room temperature at a maximum rate of $70^{\circ} \mathrm{C}$ per hour for the stress relive. Microstructure of the transverse section of the specimens was examined using conventional 
metallographic techniques.

Microhardness profiles from weld centre line $(\mathrm{C} / \mathrm{L})$ to base metal at mid-thickness of stress relived samples were taken using a Shimadzu micro-hardness tester applying $50 \mathrm{~g}$ loads for 30 seconds. Macrohardness values at base, HAZ and weld metal zones of three current settings for the as-received and stress-relieved samples were determined using a Vickers hardness tester with a square-base diamond pyramid as the indenter. At least seven indentations were made on each zone under the load $30 \mathrm{~kg}$ applied for 150 seconds. Tensile specimens were prepared from unaffected area (Base metal), base/weldment and deposited weld metal of the pipe where base/weldment sample contains half portion deposited weld metal and half portion base metal. Tensile tests were carried out according to ASTM specification at room temperature $\left(20{ }^{\circ} \mathrm{C}\right)$ in an Instron Universal Testing machine using cross head speed of $10^{-3} / \mathrm{s}$. The toughness was determined at four temperatures using five test pieces at each test temperature by standard Charpy-V impact testing machine in accordance with ASTM E23. Cryogenic test temperature $\left(-32^{\circ} \mathrm{C}\right)$ were attained by quenching the samples in liquid nitrogen for 60 minutes. Fire blower was used for the temperature $20^{\circ} \mathrm{C}, 75^{\circ} \mathrm{C}$ and $100^{\circ} \mathrm{C}$. The notches of specimen were placed at base metal, HAZ deposited weld area and regions for all current setting used.

Table 1. Chemical Composition (wt \%) of Base Metal

\begin{tabular}{lllllllll}
\multicolumn{8}{c}{ and Weld Metal } \\
\hline Material & $\mathbf{C}$ & $\mathbf{M n}$ & $\mathbf{P}$ & $\mathbf{S}$ & $\mathbf{S i}$ & $\mathbf{C r}$ & $\mathbf{M o}$ & $\mathbf{F e}$ \\
\hline $\begin{array}{l}\text { Base } \\
\text { Metal }\end{array}$ & 0.14 & 0.44 & 0.01 & 0.01 & 0.36 & 1.02 & 0.55 & bal \\
\hline $\begin{array}{l}\text { Weld } \\
\text { Metal }\end{array}$ & 0.08 & 0.45 & 0.01 & 0.01 & 0.28 & 0.78 & 0.65 & bal \\
\hline
\end{tabular}

\section{RESULTS AND DISCUSSION \\ Microstructure}

Microstudy of different zones viz. unaffected base metal, HAZ and deposited weld metal are carried out to make relationship of structure-property. Fig. 1 shows the microstructure of postweld heat treated (PWHT) base metal, HAZ and deposited weld metal. It consists basically ferrite and spheroidized pearlite with carbides which are dispersed throughout the structure. The spheroidized pearlite making the microstructure more stable is formed due to the annealing operation'. These PWHT HAZ microstructures are much finer than those of PWHT base metals. Ferrite grains were found in these postweld heat treated HAZ and carbide precipitation was found along grain boundaries. Figure 1c. shows the microstructure of deposited weld metal after PWHT done at $650^{\circ} \mathrm{C}$ for 2 hours. These microstructures are different from those of HAZ and base metal zones.
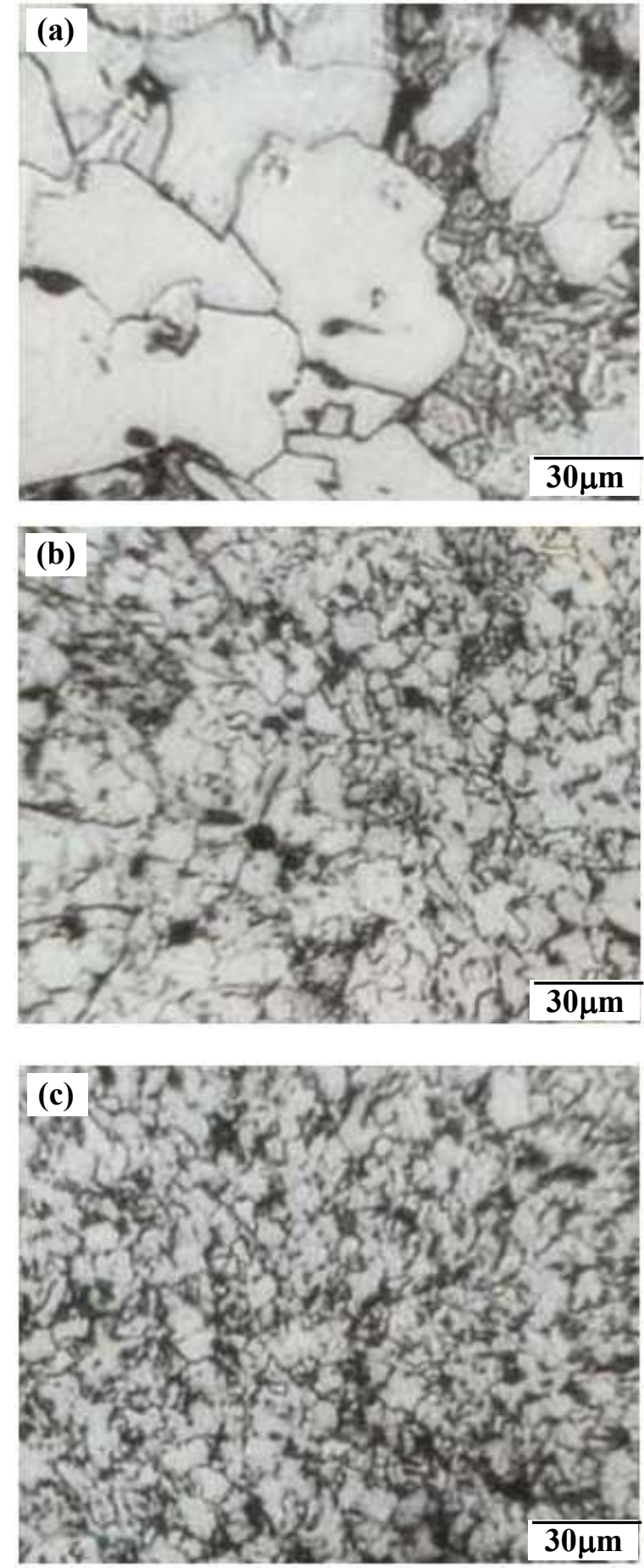

Figure 1. Optical micrographs (a) base metal (b) heat affected zone and (c) weld metal deposited at a current value of $150 \mathrm{~A}$.

In general, after welding the microstructures consist of more coarse grained structures occurring due to a sufficient level of welding heat to transform the structure to coarse austenite grain structure. However, after applying PWHT, all microstructures would transform again to ferrite structure with carbide precipitation. It is also found that HAZ microstructure 
after 6-hours PWHT consists of most coarsening ferrite grain structure ${ }^{10}$.

\section{Microhardness}

Microhardness measurement taken from weld centre line towards the base metal after stress relieving is shown in Fig. 2. It is seen that hardness decreases from the centre of the weld deposit to the base metal for the samples welded at different currents. This decreasing trend of hardness is associated with carbide precipitation and the grain size of the ferrite. It was found that the carbide precipitation decreases and ferrite grain size increases from weld metal centre line to the base metal (Fig. 1). Besides that it is thought that the hardness of weld metal increases due to the gamma prime precipitates in the matrix ${ }^{11}$. The precipitated carbides and grain boundaries make obstruction for the dislocation movement resulting in increase of hardness.

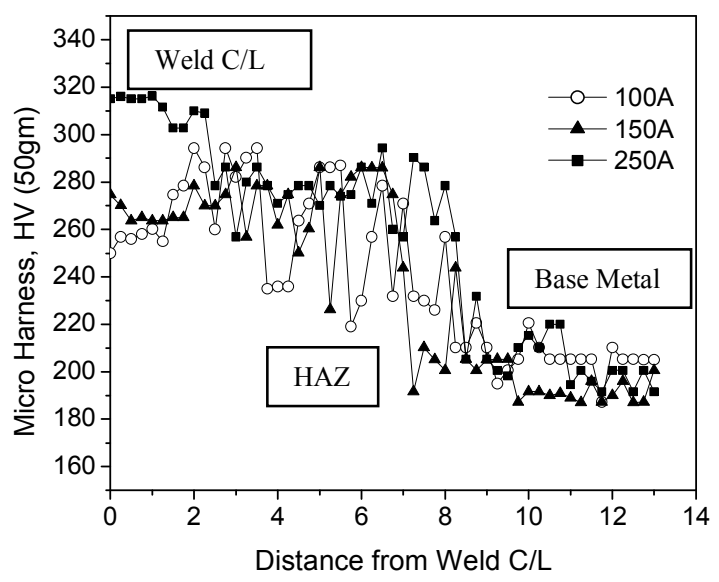

Figure 2. Showing the variation of microhardness from weld centre line to the base metal for $\mathrm{Cr}-\mathrm{Mo}$ steel welded at different currents under constant voltage.

\section{Macrohardness}

Macrohardness at base-metal, HAZ and weld deposit may indicate the structural changes that occur during the multipass of weld. Fig. 3 and Fig. 4 show the hardness at different zones before and after heat treatment at different current settings. The deposited weld area exhibits a higher hardness as compared to HAZ, and this may be attributed to high residual stress exist in weld deposit area. It is also observed that maximum hardness attains for weld deposit which has minimum heat input and reduction in microhardness from stress relieving treatment is much more pronounced for the weld deposited at $100 \mathrm{~A}$ than that for weldment deposited at $150 \mathrm{~A}$ and $250 \mathrm{~A}$. After stress relieving either the HAZ or deposited weld metal, the hardness is found to be more or less similar for any current settings.

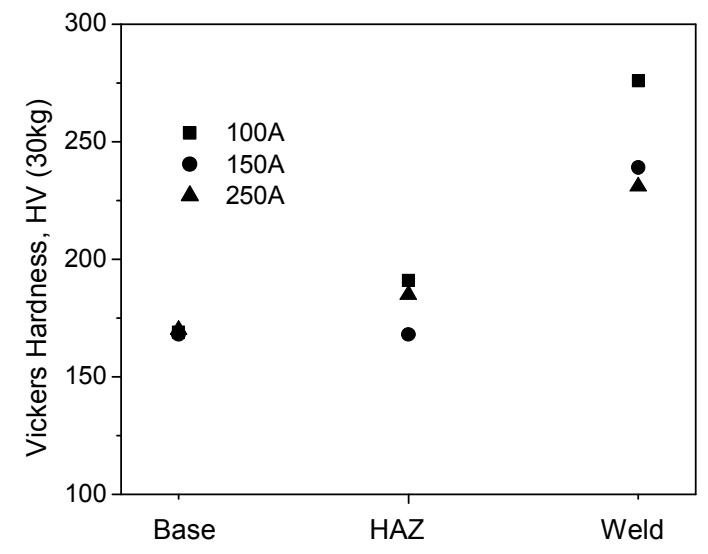

Figure 3. Variation of hardness of different zones measured at room temperature for Cr-Mo steel welded at various current settings as received condition.

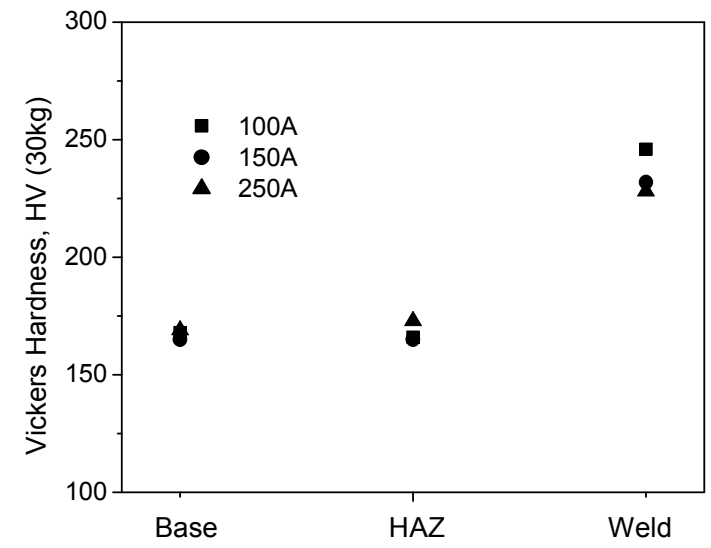

Figure 4. Variation of macro hardness of different zones measured at room temperature for $\mathrm{Cr}-\mathrm{Mo}$ steel welded at various current settings PWHT condition.

\section{Tensile Strength}

In the present investigation, tensile tests have been carried out at room temperature $\left(20^{\circ} \mathrm{C}\right)$ for stress relieved (PWHT) base-metal, base/weldment and deposited weld metal test piece. The tensile properties of these specimens are given in Table 2. It is seen that the YS and UTS of the weld metal is higher than the base metal and base/weldment welded at $150 \mathrm{~A}$. For base/weldment, necking takes place in plate region. It is found that the base/weldment and deposited weld metal YS and UTS is higher than the base-metal deposited at 150 A current setting. But the base/weldmetal deposited at 150 A shows the higher YS, UTS and lower \% elongation than those of deposited at $100 \mathrm{~A}$ and $250 \mathrm{~A}$.

It can be noted that values of YS and UTS of base/weldment do not represent the true properties of weldment but these values are reported as an indication of any change of property especially change in microstructure occurs in heat affected zone (HAZ) and weld metal. Carbide dissolution and grain 
growth can occur in HAZ region during welding, so this region might exhibit slightly lower strength than that of the base metal. The microstructure of deposited weld metal at 100, 150 and 250 A current settings clearly reveals the finer grain structure than that of the base-metal as shown in Fig. 1. It is also true that a precise correlation between grain size alone and mechanical properties is not possible since these may be influenced by the morphology and distribution of carbides, the presence of grain boundary precipitates and other features. But it is thought that the fine ferrite grain and carbide precipitates are responsible for the increase of the yield strength of deposited weld metal as compared to the base metal and base/weldment.

Table 2. Mechanical Properties of base-metal, base/ weldment and weld-metal at room Temperature

\begin{tabular}{lccc}
\hline Material & $\begin{array}{c}\text { YS } \\
{[0.2 \% \mathrm{PS}]} \\
\mathrm{MPa}\end{array}$ & $\mathrm{MPa}$ & $\begin{array}{c}\text { Elongation } \\
\%\end{array}$ \\
\hline Base-Metal & 404 & 540 & 27 \\
\hline $\begin{array}{l}\text { Base/Weldment } \\
(\mathbf{1 0 0} \text { ) })\end{array}$ & 500 & 579 & 17 \\
\hline $\begin{array}{l}\text { Base/Weldment } \\
(\mathbf{1 5 0} \text { A) }\end{array}$ & 570 & 635 & 19 \\
\hline $\begin{array}{l}\text { Base/Weldment } \\
(\mathbf{2 5 0} \text { ) })\end{array}$ & 529 & 625 & 22 \\
\hline $\begin{array}{l}\text { Weld-Metal } \\
(\mathbf{1 5 0} \text { A) }\end{array}$ & 615 & 686 & 23 \\
\hline
\end{tabular}

\section{Impact Energy}

The results for impact energy of deposited weld metal and HAZ of PWHT samples at different current settings are plotted as a function of temperature and are shown in Fig. 5 and Fig. 6 respectively.

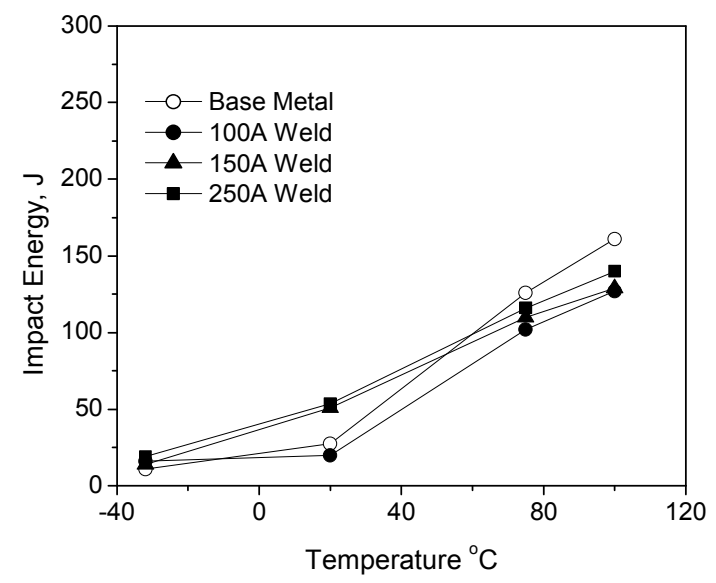

Figure 5. Impact energy-temperature relationships for Cr-Mo base steel and deposited weld metal at various current settings.

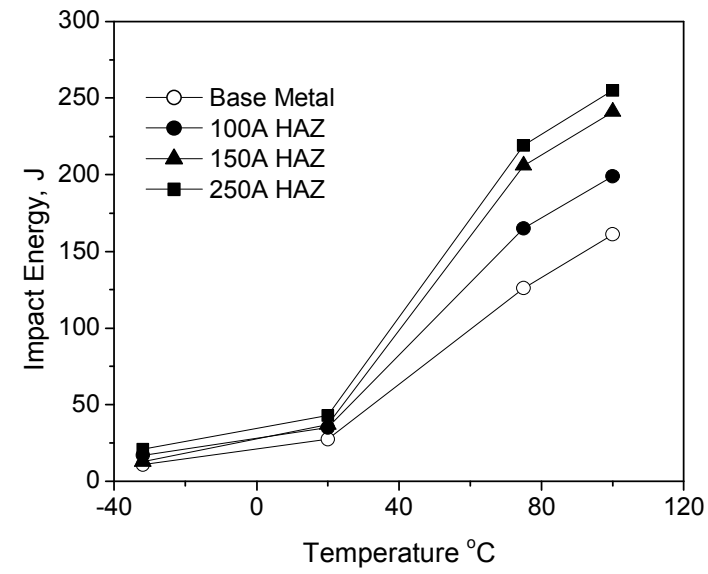

Figure 6. Impact energy-temperature relationships for Cr-Mo base steel and HAZ at various current settings.

It is seen from those figures that the impact energy is the lowest for both the weld deposit and HAZ when tested at cryogenic temperature $\left(-32^{\circ} \mathrm{C}\right)$ and no significant change occurs with changing the current. This is due to the brittle fracture of the metals on the fracture mode changes to the brittle from ductile mode at the cryogenic test temperature. With increasing test temperature the impact energy absorbed increases for both the weld deposit and HAZ as the metal fracture mode change to brittle to ductile at higher temperature ${ }^{6}$. It is also observed from Fig. 5 and Fig. 6 that at higher temperature impact energy increases with increasing welding current as well as higher heat input for both zones. It is thought that with increasing heat input, the grain size becomes finer which are pinned with molybdenum and chromium carbide particles. Impact energy absorbed by HAZ at higher temperature is found to higher as compared to weld deposit because the coarsening of ferrite grain of HAZ occurs with higher heat input.

\section{CONCLUSION}

It is found that the ferrite grains become finer and carbide precipitation increases from the base metal to deposited weld metal when welded at different currents. This variation in microstructure gives the varying hardness in the base, HAZ and weld regions at any current settings and deposited weld metal region shows the maximum hardness. Microhardness of the weld metal is found to increase with the increase of welding current. Besides maximum yield strength and ultimate tensile strength is found in the deposited weld metal welded at 150A current. At cryogenic temperature (sub-zero temperature), it is observed that all the regions are not sensitive to toughness with different welding currents. The impact energy absorbed of deposited weld metal area is lower than that of HAZ area at any current settings and test temperature. Increasing of impact energy absorbed in 
deposited weld is also observed with the increase of welding current tested at different temperature.

\section{REFERENCES}

1. Kumslytis, V., Skindaras, R. and Valiulis, V., "The Structure and Properties of 5\%Cr-0.5\%Mo Steel Welded Joints after Natural Ageing and Post-weld Heat Treatment," Materials Science Technology. ISSN 1392-1320, Vol. 18, no.2, 2012, pp. 119-122.

2. Mohapatra, J. N., Panda, A. K., Gunjan, M. K., Bandyopadhyay, N. R., Mitra, A. and Ghosh, R. N., "Ageing Behaviour Study of $5 \mathrm{Cr}-0.5 \mathrm{Mo}$ Steel by Magnetic Barkhausen Emissions and Magnetic Hysteresis Loop Techniques," NDT \& E International, Vol. 23, No. 2, 2007, pp. 173-178.

3. Orie, K., Roper, Ch. R. and Upitis, E., "The Effect of Post Weld Heat Treatment and Notch Toughness on Welded Joints and on Normalized Base - Metal Properties of A516 Steel," WRC Bulletin 481, New York Welding Research Council, Inc, 2003, pp 8384.

4. Jurcius, A., Valiulis, A. V. and Kumslytis, V., "Vibratory Stress Relieving - It's Advantages as an Alternative to Thermal Treatment" J. of Vibroengineering, Vol. 10, No. 1, 2008, pp. 123-127.

5. Sae-teaw N., Poopat B., Phung-on I. and Chairuangsri T., "Analysis of Microstructure in Soft Zone and Precipitation Zone of Dissimilar Cr-Mo Steels Weldment," AIJSTPME, Vol. 3, No. 2, 2010, pp. 57-64.
6. Muratoglu, M. and Eroglu, M., " Effect of molybdenum on the intercritical heat-affected zone of the low carbon Cr-Mo steel," Asian Transaction on Engineering, Vol. 1, No. 4, 2011, pp. 1-5.

7. Srivastava, B. K., Tewari, S. P. and Prakash, J., "A review on effect of preheating and/or post weld heat treatment (PWHT) on mechanical behavior of ferrous metals," International J. of Engineering Science and Technology, Vol. 2, No. 4, 2010, pp. 625-631.

8. Yoshihiro, S., Kohsuke, H. and Hisaya, K. ."Welding heat-input limit of rolled steels for building structures based on simulated HAZ tests," Transactions of JWRI, Vol. 30, No. 1, 2001, pp. 127134.

9. Miche, J., Bursak, $\mathrm{M}$ and Vojtko, M., "Microstructure and mechanical properties degradation of Cr-Mo creep resistant steel operating under creep conditions," J. of Materials Engineering, Vol. 18, 2011, pp. 57-62.

10.Peddle, B. E. and Pickles, C. A., "Carbide and hardness development in the heat- affected zone of tempered and postweld heat-treated $2.25 \mathrm{Cr}-1 \mathrm{Mo}$ steel weldments," J. Mater. Eng. Perform. Vol. 9, No. 5, 2000, pp. 477-488.

11. Tammasophon, N., Homhrajai, W. and Lothongkumi, G., "Effect of Postweld Heat Treatment on Microstructures and Hardness of TIG Weldment between P22 and P91 Steels with Inconel 625 Filler Metal," J. of Metals, Materials and Minerals, Vol. 21 No. 1, 2011, pp.93-99. 